\title{
A Survey and Analysis of the Relationship between Human Resources Management and Organizational Performance
}

\author{
Seyed Ahmad Hashemi \\ Department of Government Management \\ E-campus \\ Islamic Azad University \\ Tehran, Iran
}

\author{
Farideh Dehghanian \\ Department of Government Management \\ E-campus \\ Islamic Azad University \\ Tehran, Iran
}

\begin{abstract}
This study aims to evaluate the relationship between human resources management and organizational performance with emphasis on the mediating role of organizational innovation. The study methodology is descriptive-correlation and structural equations modeling. The study population is employees of the electricity distribution company of Tehran city. The reliability and validity of measures were evaluated using Cronbach's alpha and confirmatory analysis and the results showed the acceptable reliability and validity of measures. For data analysis, Pearson Correlation coefficient and structural equations method with Lisrel software were used. The results showed that the effect of organizational innovation mediating variable was indirectly 0.17 meaning that if human resources management is increased as $1 \%$, the organization performance with the mediating role of organizational innovation is increased as $16 \%$. This study evaluates the relationship between human resources management and organizational performance with emphasis on the mediating role of organizational innovation.
\end{abstract}

Keywords-Human resources management; Organizational innovation; Organizational performance.

\section{INTRODUCTION}

In most organizations, leaders and managers attempt to promote and improve their performance. Previous studies results emphasized on the role of human resources management and organizational innovation in the improvement of organizational performance. A few studies evaluated the direct and indirect effects of mentioned variables on the framework of structural equations modeling on organizational performance. Thus, the evaluation of these is necessary. Nowadays, non-assurance, complexity, globalization and increasing technological changes are considered important features. Innovation, creativity and problem solving capability are key skills [1]. Creativity and innovation are required for the durability of each organization and non-innovative organizations are eliminated over time [2]. The organization that can present new thoughts can accept changes well and can also act as a factor of making changes. Thus, it is necessary for organizations to use creativity and innovation or else they are threatened with elimination from the competition. Thus, it is necessary to identify the predictors and outcomes of organizational innovation. Electricity distribution company of Tehran attempts to use new strategies, including the use of a proposition system and its active use in decision making process, maximum use of existing human resources, development of participation in all levels, recognition, development and prosperity of existing human resources, increase of empathy and collaboration, qualitative and quantitative improvement of activities and the increase of satisfaction and innovation of employees. The increase of motivation, improvement of human relationships, achieving optimal service providing methods, decision making, saving in organization, accepting the positive changes and implementation of productivity techniques can improve the performance of this company. Based on the necessity in the approach of electricity industry to use new advanced technologies to improve performance, the innovation of employees is of great importance. Based on the electricity distribution company of Tehran, we can say low level of innovation of employees in an organization can endanger its performance. The important role of human resources management for the organization's survival can oblige the electricity distribution company of Tehran to adapt to the increasing complexities and rapid changes. Under such spaces, the organizations with high creativity can respond rapidly to the environmental challenges and they have better performance compared to that of non-creative organizations. Thus, due to the importance of performance and innovation, the identification of effective factors on these variables is of great importance. The present study evaluates the relationship between human resources management and organizational performance with emphasis on the mediating role of organizational innovation [3].

\section{THEORETICAL BASICS}

- Human resources management: Human resources management is defined as the arrangement and activities of planned human resources model with the goal that the organization is enabled to achieve its goals [4]. 
- Education: Education is experience based on learning. Normally, it is said that education can lead to the change of skills, knowledge, attitude and social and organizational behavior [5].

- Employees' participation: Creating a space in which all organization employees collaborate and participate in decision making process and resolving the organization problems with the management [3].

- Performance assessment: Performance assessment refers to the measurement of employee performance [3].

- Job analysis: Job analysis refers to the definition of responsibilities and job position of employees and revision in those responsibilities under necessary conditions [3].

- Employee's development: Employees development refers to the opportunities provided by the organization for the employees to progress in their job [3].

- Organizational innovation: Organizational innovation refers to the development or acceptance of a new idea or behavior in business operation [6].

- Innovation production: Innovation production refers to presenting new ideas for job improvement, using new methods, new work techniques and coming up with new solutions [6].

- Innovation improvement: Innovation improvement refers to stimulating innovative ideas [6].

- Innovation execution: Innovation execution refers to turning the innovative thought to useful methods [6].

- Organizational performance: Performance means the result and amount of work. In another definition, it is the amount of results achieved by a person, team organization or process [4].

\section{RESEARCH BASICS}

Authors in [7] evaluated the correlation of human resources strategies based on the model of Allen Yelsi with the organizational performance of the employees of Ayatollah Kashani hospital of Shahre Kord. The results showed that there was a significant correlation between human resources strategy and organizational performance. Authors in [8] conducted a study to evaluate the impact of knowledge management strategies on innovation and organizational performance. The results showed that knowledge management had positive impact on organizational innovation and performance. In addition, organizational innovation had positive and direct impact on organizational performance. Authors in [9] evaluated the relationship between human resources strategic management and firm performance. The study findings showed that the companies following the activity of human resources strategic management have better performance compared to the companies that don't. Author in [3] evaluated the relationship between human resources management, organizational innovation and organizational performance in the framework of structural equations in the companies with high performance. The results showed that human resources management was effective on organizational innovation and performance. In [4], authors evaluated the impact of human resources strategic management on organizational performance, based on the mediating role of organizational learning processes in Korean organizations. It was found that the strategic management of human resources had a positive and significant impact on the organizational learning processes and organizational performance. The organizational learning processes had positive and significant impact on organizational performance. Authors in [10] evaluated the relationship between knowledge management, strategic orientation, organizational innovation and organizational performance. It was found that knowledge management had a direct impact on strategic orientation but the relationship between other variables was not significant. Authors in [6] evaluated the relationship between innovation, organizational learning and performance. The results showed that innovation and organizational learning had positive impact on commercial performance and organizational learning had positive impact on organizational innovation.

\section{STUDY POPULATION, SAMPLE SIZE AND SAMPLING METHOD}

The study population of the present study is the 250 employees of the electricity distribution company of Tehran. Based on the sample study, to determine the sample size, Cochran's formula is used:

$$
\mathrm{n}=\frac{N \mathrm{t}^{2} \mathrm{~s}^{2}}{N \mathrm{~d}^{2}+\mathrm{t}^{2} \mathrm{~s}^{2}}
$$

Thus, 151 employees of electricity distribution of Tehran are selected as the study sample. The sampling method in the present study is simple random method.

\section{A. Introduction of Study Measures}

The variables of the present study are the methods of human resources management, organizational innovation and organizational performance. To evaluate each of the variables, standard questionnaires were used.

- Human resources management: To measure human resources management, the questionnaire presented in [11] is applied. This questionnaire is composed of 19 items. The questions are scored based on Likert scale (totally disagree $=1$, totally agree $=5$ ).

- Organizational innovation: To measure organizational innovation a questionnaire composed of 9 items is applied. The questions are scored based on Likert scale (totally disagree $=1$, totally agree $=5$ ).

\section{B. Determine Validity and Reliability of Study Measures}

The measure validity and reliability are the most important factors in a study. To determine the test reliability in this study, Cronbach's alpha is used. This method is used to calculate the internal consistency of measures measuring the different attributes. To calculate Cronbach's alpha coefficient, at first we should calculate the variance of scores of each sub-set of 
questions of questionnaire and total variance. Then, by the following formula, alpha coefficient value is calculated.

$$
r_{\alpha}=\frac{J}{J-1}\left(1-\frac{\sum_{j=1}^{n} s_{j}^{2}}{S^{2}}\right)
$$

In this study, alpha above 0.7 is a suitable for the reliability. Thus, measurement of reliability is performed using Cronbach's alpha and SPSS 18 software. To evaluate validity of measures, besides the content validity, confirmatory factor analysis is used.

\section{Data Analysis Methods}

To analyze the data of this study, descriptive and inferential tests were used. In descriptive section, percent, mean and standard deviation and in inferential section, Pearson correlation and structural equations modeling were used. For data analysis, SPSS, LISREL software were used.

\section{STUDY RESULTS}

\section{A. Evaluation of the Demographic Features of Study Sample}

Study findings show that $19.86 \%$ of respondents are women and $80.14 \%$ men. $42.47 \%$ have a diploma, $48.63 \%$ BA and $8.90 \%$ MA and above. $31.51 \%$ of the respondents are at the age group of $30-40$ years, $43.83 \%$ at $41-50$ and $24.66 \%$ are above 51 years old. The respondents with 10-15 years of experience are $7.53 \%, 64.39 \%$ have $16-20$ years of experience and $28.08 \%$ above 20 years.

\section{B. Descriptive Indices of Study Variables}

Table I shows the indices of descriptive statistics for the study sample as mean and standard deviation for the studied variables.

TABLE I. THE DESCRIPTIVE INDICES OF STUDY VARIABLES

\begin{tabular}{|c|c|c|}
\hline SD & Mean & Variables \\
\hline 0.72 & 3.09 & Human resources management \\
\hline 1.06 & 2.74 & Organizational innovation \\
\hline 0.94 & 2.86 & Organizational performance \\
\hline
\end{tabular}

\section{Evaluation of Normality of Data}

At first, the normality and non-normality of data is determined and then the study hypotheses are evaluated. To evaluate data normality, Kolmogorov-Smirnov test was used. As shown in Table II, Kolmogorov-Smirnov test for all variables is not significant. Thus, the study variables are normal and Pearson correlation and structural equations modeling are used for stud hypothesis testing. The results of correlation coefficient are shown in Table III. The results show that correlation coefficient of human resources management with organizational innovation $(\mathrm{r}=0.51)$ and organizational performance $(\mathrm{r}=0.53)$ is significant and positive at the level $\mathrm{p}<0.01$. The correlation coefficient of organizational innovation with organizational performance $(\mathrm{r}=0.48)$ is significant and positive at the level $\mathrm{p}<0.01$. Figure 1 shows the tested model with the standardized values on each path. The results show that the effective of human resources management on organizational innovation and organizational performance is positive and significant. The effect of innovation on organizational performance is positive and significant. Figure 2 shows the $\mathrm{t}$-valued of tested model. T-values above \pm 1.96 to 2.58 are significant at the level 0.05 and $\mathrm{t}$-values above \pm 2.58 are significant at the level 0.01. As shown in Figure 2, t-values show that all coefficients are significant. Table IV shows the path coefficients of study variables.

\section{Correlation Coefficient of Variables}

After determining the validity of measures, the identification of the relationship between the variables is the next step. To identify the relationship between the presented variables, Pearson correlation coefficient is used. As shown in Table IV, the direct effect of human resources management on organizational innovation $(\beta=0.59)$ and organizational performance $(\beta=0.44)$ is positive and significant at the level 0.01 . The direct effect of organization innovation $(\beta=0.28)$ on organizational performance is positive and significant. The indirect effect of human resources management on organizational performance via organizational innovation $(\beta=0.17)$ is positive and significant at the level 0.01 . The $41 \%$ variance of organizational performance and $34 \%$ variance of organizational innovation are explained by the existing variables in the present study. The fit indices of the tested model in Table $\mathrm{V}$ show that RMSEA index in the estimated model with 0.023 is acceptable and other fit indices as CFI, GFI, NFI, AGFI are 1, 0.96, 0.99 and 0.93 respectively, which is at suitable level. This shows that the study data have good fit with the factor structure.

TABLE II. KOLMOGOROV-SMIRNOV TEST OF STUDY VARIABLES

\begin{tabular}{|c|c|c|}
\hline Significance level & $\mathbf{Z}$ & Variables \\
\hline 0.644 & 0.740 & Human resources management \\
\hline 0.071 & 1.292 & Organizational learning \\
\hline 0.375 & 0.913 & Organizational performance \\
\hline
\end{tabular}

TABLE III. THE CORRELATION MATRIX OF STUDY CONSTRUCTS

\begin{tabular}{|c|c|c|c|}
\hline Variables & $\mathbf{1}$ & $\mathbf{2}$ & $\mathbf{3}$ \\
\hline Human resources management & 1 & & \\
\hline Organizational innovation & $* * 0.51$ & 1 & \\
\hline Organizational performance & $* * 0.53$ & $* * 0.48$ & 1 \\
\hline \multicolumn{4}{|c|}{$* \mathrm{p}<0.05 * * \mathrm{p}<0.01$} \\
\hline
\end{tabular}

TABLE IV. PATH COEFFICIENTS OF STUDY VARIABLES.

\begin{tabular}{|c|c|c|c|c|}
\hline Path & $\begin{array}{l}\text { Direct } \\
\text { effect }\end{array}$ & $\begin{array}{c}\text { Indirect } \\
\text { effect }\end{array}$ & $\begin{array}{l}\text { Total } \\
\text { effect }\end{array}$ & $\begin{array}{c}\text { Explained } \\
\text { variance }\end{array}$ \\
\hline $\begin{array}{l}\text { On Organizational } \\
\text { performance from }\end{array}$ & & & & \multirow{3}{*}{$41 \%$} \\
\hline Organizational innovation & $0.28^{* *}$ & & $0.28^{* *}$ & \\
\hline Human resources management & $0.44^{* *}$ & $0.17^{* *}$ & $0.61^{* *}$ & \\
\hline $\begin{array}{c}\text { On organizational innovation } \\
\text { from }\end{array}$ & & & & \multirow[t]{2}{*}{$34 \%$} \\
\hline Human resources management & $0.59 * *$ & - & $0.59 * *$ & \\
\hline
\end{tabular}




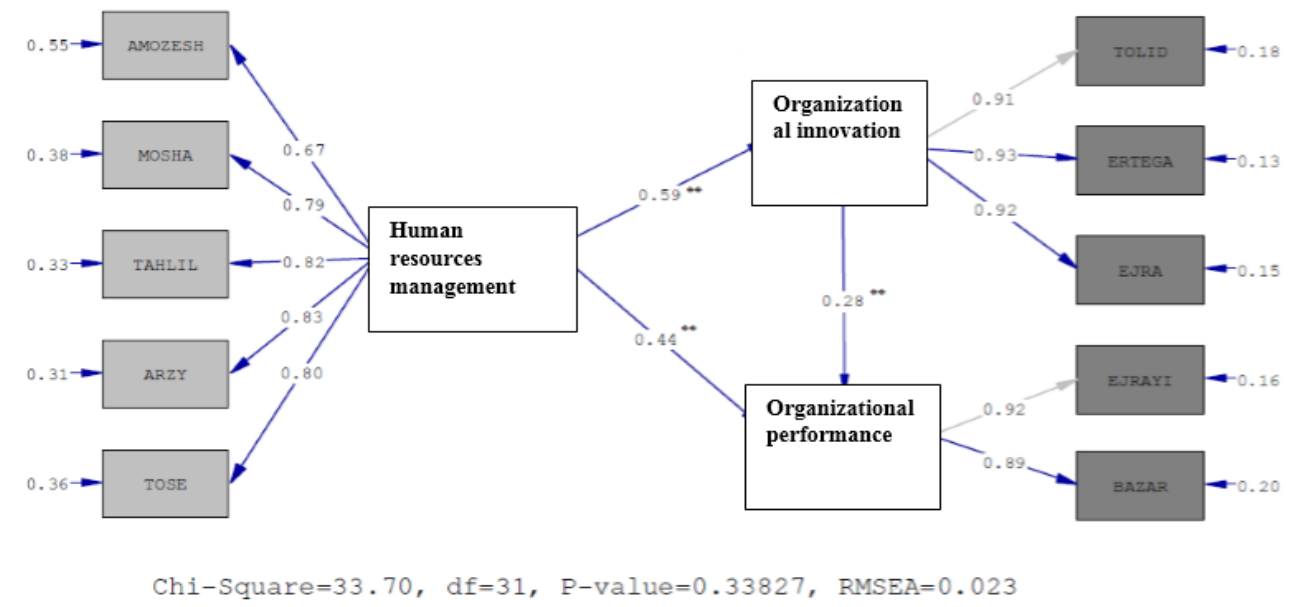

Fig. 1. The tested model of study $(* \mathrm{p}<0.05 * * \mathrm{p}<0.01)$

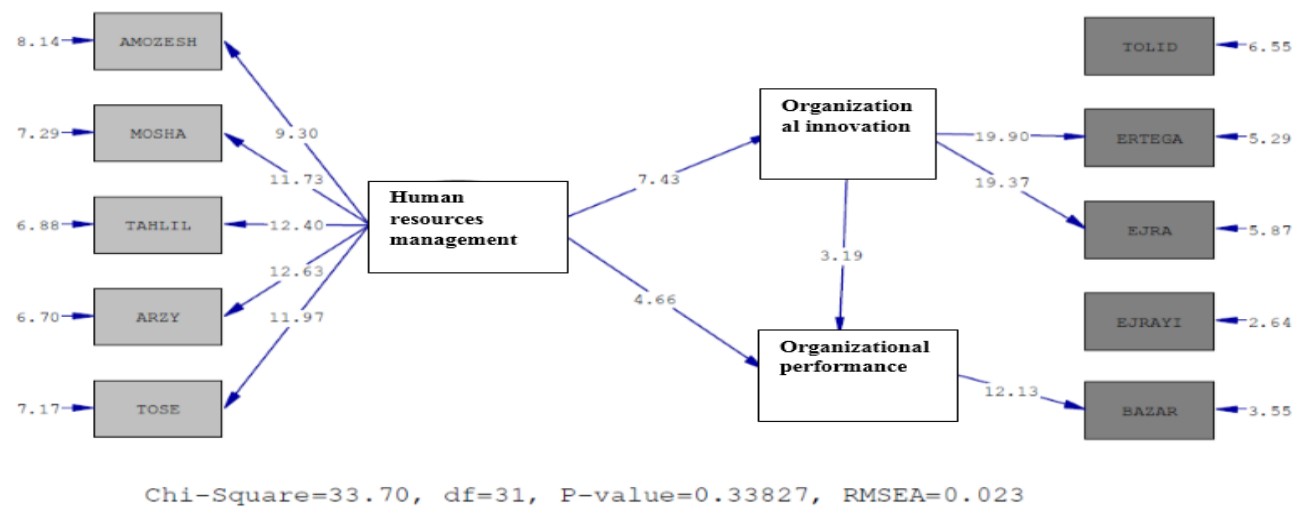

Fig. 2. $\mathrm{t}$-value of tested model of study $(* \mathrm{p}<0.05 * * \mathrm{p}<0.01)$

TABLE V. THE FIT INDICES OF FITTED MODEL

\begin{tabular}{|c|c|c|c|c|c|}
\hline x/df & RMSEA & CFI & GFI & NFI & AGFI \\
\hline 1.09 & 0.023 & 1 & 0.96 & 0.97 & 0.93 \\
\hline
\end{tabular}

\section{E. Hypothesis test}

Overall results hypothesis test are shown in Table VI.

\section{1) First hypothesis:}

There is a significant relationship between human resources management (education, participation, job analysis, performance evaluation and employee development) with organizational performance (executive and market). The results of structural equations showed that the effect of human resources management on organizational performance was positive and significant. This result is consistent with the results of [12] and [3]. The continuous employee education, the teaching of new skills, the consideration of employee's opinions, the initiative encouragement, the objective employee evaluation, the offered career opportunities are among the things making the employees to have high motivation to improve personal and therefore organizational performance.
TABLE VI. STUDY HYPOTHESES TEST

\begin{tabular}{|c|c|c|}
\hline Hypothesis & $\begin{array}{c}\text { Path } \\
\text { coefficient }\end{array}$ & $\begin{array}{c}\text { Supported/ } \\
\text { Rejected }\end{array}$ \\
\hline $\begin{array}{c}\text { There is a significant relationship } \\
\text { between human resources management } \\
\text { with organizational performance }\end{array}$ & 0.44 & supported \\
\hline $\begin{array}{c}\text { There is a significant relationship } \\
\text { between human resources management } \\
\text { with organizational innovation }\end{array}$ & 0.59 & supported \\
\hline $\begin{array}{c}\text { There is a significant relationship } \\
\text { between organizational innovation and } \\
\text { organizational performance }\end{array}$ & 0.28 & supported \\
\hline $\begin{array}{c}\text { Organizational innovation in the } \\
\text { relationship between human resources } \\
\text { management and organizational } \\
\text { performance has a mediating role. }\end{array}$ & 0.17 & supported \\
\hline
\end{tabular}

2) Second hypothesis:

There is a significant relationship between human resources management (education, participation, job analysis, performance evaluation and employees development) with organizational innovation (production, promotion and 
execution of innovation). The results of structural equations showed that the effect of human resources management on organizational innovation was positive and significant. Thus, the involvement of human resources in varied duties is effective on organizational innovation. The goal of investment in human resources management is the emphasis on the employee improvement with continuous learning and education. This result is consistent with [13] stating that the organizations by using effective strategies of human resources can create some features and behavior in the employees which are necessary for the organization success. Today, the importance of human factor and its unique role as a strategic source is increased. Today, the organizations use human resources with rapid growth, continuous improvement, efficacy, effectiveness, flexibility, preparation for the future and excellent position in their activities. Organizations without these qualities, organizations enter the competition with a handicap. Via human resources management methods, the organizations can create organizational innovation.

\section{3) Third hypothesis:}

There is a significant relationship between organizational innovation (production, promotion and execution of innovation) and organizational performance (executive and market). The results of structural equations showed that the effect of organizational innovation on performance is positive and significant. We can say innovation is the source of system change for progress. Via innovation the organization equips itself with new tools, methods and techniques and it is aware of the latest progress and knowledge and by using them, optimization is improved leading to the improvement of organizational performance [14].

\section{4) Fourth hypothesis:}

Organizational innovation (production, promotion and execution of innovation) in the relationship between human resources management (education, participation, job analysis, performance evaluation and employee development) and organizational performance (executive and market) has a mediating role. The results of structural equations showed that the indirect effect of human resources management on organizational performance was positive and significant. This result emphasizes on the mediating role of organizational innovation in the relationship between human resources management and organizational performance.

\section{CONCLUSION}

The results showed that the direct and indirect effect of human resources management on organizational performance was positive and significant. Thus, the results of study emphasize on the role of organizational innovation as an important mediator. If human resources management applies education, participation of employees, job analysis, objective evaluation of performance and development of employees, organizational innovation is provided affecting the organization performance. The human resources management methods should be applied in creating organization's processes, services and products. If the organization cannot use the human resources management, it cannot achieve competitive advantages.

\section{RECOMMENDATIONS}

It is proposed to the managers of the electricity distribution company of Tehran to use competence methods of human resources in human resources management, i.e. to apply improvement opportunities and job development for the employees, provide learning opportunities, support good decision making and evaluate employees based on their performance. These can affect the organizational innovation and organizational performance. It is proposed to the managers of electricity distribution of Tehran to provide the conditions in which the employees are encouraged to present new ideas and solutions, to search new tools, methods and techniques, to support innovative ideas, to attempt to turn innovative thought to useful methods, to relate innovative thought with the work and to evaluate the effectiveness of innovative thought by which organizational performance is improved.

\section{REFERENCES}

[1] A. Monavarian, N. Asgari, Organizations in the age of industry, information and knowledge, Tehran publication, 2009

[2] H. Mohammadi, M. Tabari, "Institutionalize creativity and innovation in organization", Journal of Tadbir, Vol. 1, No. 1, pp. 201- 202, 2008

[3] K. Lu, J. Zhu, H. Bao, "High-performance human resource management and firm performance: The mediating role of innovation in China", Industrial Management \& Data Systems, Vol. 115, No. 2, pp. 353-382, 2015

[4] I. H. S. Chow, S. T. Teo, I. K. Chew, "HRM systems and firm performance: The mediation role of strategic orientation", Asia Pacific Journal of Management, Vol. 30, No. 1, pp. 53-72, 2013

[5] M. Silberman, C. Auerbach, Metody aktywizujące w szkoleniach, Wolters Kluwer Polska, 2009

[6] D. Jimenez-Jimenez, R. Sanz-Valle, "Innovation, organizational learning, and performance", Journal of Business Research, Vol. 64, No. 4, pp. 408-417, 2011

[7] M. Nasiri, M. Heidari, S. Shahbazi, E. Ansari, "Correlation of human resource strategies based on Allen Ylsy Model with organizational performance staff in Aiat Allah Kashani Hospital", Journal of Health Promotion Management, Vol. 2, No. 3, pp. 36-44, 2013

[8] H. Safarzadeh, A. Tadayon, M. HorMohammadi, "The Evaluation of Effects of Knowledge Management Strategy on Organizational Innovation and Performance (A case study in community health centers of north part of Fars province)", The Journal of Toloo-e-behdasht, Vol. 11, No. 1, pp. 65-76, 2012

[9] S. A. Efje, M. Esmailzade, "The evaluation of the relationship between human resources strategic management and performance of firms", Development and Change Management, Vol. 1, No. 2, pp. 20-25, 2009

[10] A. A. Ferraresi, C. O. Quandt, S. A. dos Santos, J. R. Frega, "Knowledge management and strategic orientation: leveraging innovativeness and performance", Journal of Knowledge Management, Vol. 16, No. 5, pp. 688-701, 2012

[11] J. E. Delery, D. H. Doty, "Modes of theorizing in strategic human resource management: Tests of universalistic, contingency, and configurational performance predictions", Academy of Management Journal, Vol. 39, No. 4, pp. 802-835, 1996

[12] J. Bae, J. J. Lawler, "Organizational and HRM strategies in Korea: Impact on firm performance in an emerging economy", Academy of Management Journal, Vol. 43, No. 3, pp. 502-517, 2000

[13] R. S. Schuler, S. E. Jackson, "Linking competitive strategies with human resource management practices", The Academy of Management Executive, Vol. 4, No. 1, pp. 207-219, 1987

[14] H. Zarei Matin, Advanced Organizational Behavior Management, Tehran, Agah Publication, 2009 